\title{
Article
}

\section{Do female offenders differ? Comparing the criminal histories of serious violent perpetrators with a control sample}

Coleman, Rebecca, Almond, Louise and Mcmanus, Michelle Ann

Available at http://clok.uclan.ac.uk/19810/

Coleman, Rebecca ORCID: 0000-0001-6423-2116, Almond, Louise and Mcmanus, Michelle Ann ORCID: 0000-0002-0095-1071 (2017) Do female offenders differ? Comparing the criminal histories of serious violent perpetrators with a control sample. Journal of Investigative Psychology and Offender Profiling . ISSN 1544-4759

It is advisable to refer to the publisher's version if you intend to cite from the work. http://dx.doi.org/10.1002/jip.1485

For more information about UCLan's research in this area go to http://www.uclan.ac.uk/researchgroups/ and search for <name of research Group>.

For information about Research generally at UCLan please go to http://www.uclan.ac.uk/research/

All outputs in CLoK are protected by Intellectual Property Rights law, including Copyright law. Copyright, IPR and Moral Rights for the works on this site are retained by the individual authors and/or other copyright owners. Terms and conditions for use of this material are defined in the policies page.

\section{CLoK}

Central Lancashire online Knowledge www.clok.uclan.ac.uk

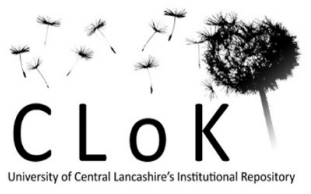




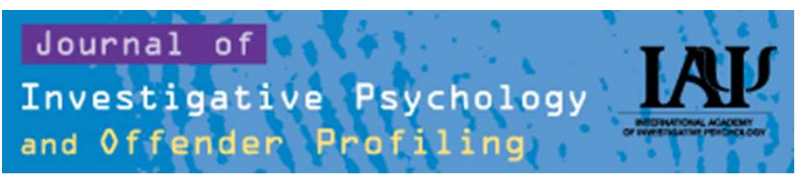

Do Female Offenders Differ? Comparing the criminal histories of serious violent perpetrators with a control sample

\begin{tabular}{|r|l|}
\hline Journal: & Journal of Investigative Psychology and Offender Profiling \\
\hline Manuscript ID & JIP-16-0010.R1 \\
\hline Wiley - Manuscript type: & Research Article \\
\hline Keywords: & $\begin{array}{l}\text { female offenders, homicide, violent offenders, serious violent, criminal } \\
\text { history }\end{array}$ \\
\hline
\end{tabular}

SCHOLARONE ${ }^{\mathrm{m}}$

Manuscripts 
Running head: DO FEMALE OFFENDERS DIFFER?

Do Female Offenders Differ? Comparing the criminal histories of serious violent perpetrators with a control sample

Keywords: serious violent, female offenders, homicide, violent offenders, criminal history 


\title{
DO FEMALE OFFENDERS DIFFER?
}

\begin{abstract}
In view of earlier research, female offenders have not received as much attention as male perpetrators. Thus, the research aimed to gain insight into the types of offences committed by serious violent female offenders $(n=206$; those who had committed grievous bodily harm, attempted murder, or homicide) and to explore differences with control female perpetrators (n $=447$ ); control offenders were matched according to age and year of offence of the serious violent offenders. The purpose was to therefore gather an understanding of female offenders, and to determine if the serious violent perpetrators differed from the control sample. A UK police force provided data of offences committed between April 2001 and April 2011. Descriptive information was analysed, with comparisons being made using Mann-Whitney U tests and Chi-Square analysis. $72.3 \%(n=149)$ of serious violent offenders had one or more recorded convictions, and were significantly more likely to have committed a previous violent offence, than the control sample. On the other hand, control perpetrators had a higher likelihood of having previously committed a theft-related offence, when compared to serious violent females. Therefore, the findings indicate the types of offences committed by female offenders and highlight the differences between serious violent perpetrators and offenders in the control sample. The implications, limitations and suggestions for future research are discussed.
\end{abstract}


DO FEMALE OFFENDERS DIFFER?

\section{Introduction}

Criminal literature has, for many decades, concentrated on male perpetrators, with female offenders receiving little attention (Campbell, 1993; Thornton, Graham-Kevan, \& Archer, 2012). Limitations relating to female offending links to the topic of gender differences; there are current arguments for a gender-neutral perspective to crime (Andrews \& Dowden, 2006; Nicholls \& Petrila, 2005), with a lack of empirical support for innovative gendered methods stated in literature (e.g. Havens, Ford, Grasso \& Marr, 2012; Heilbrun, DeMatteo, Marczyk, \& Goldstein, 2008) despite counterclaims that females may have different trajectories to offending (e.g. Leschied, 2011). Although criminal practices that have been developed on male samples are argued to be applicable to females (e.g. Heilbrun et al., 2008; Murphy, Brecht, Huang, \& Herbeck, 2012; van Voorhis, Wright, Salisbury, \& Bauman, 2010), if male and female offenders do differ, employing poorly informed practices to females would not result in effective outcomes (Dvoskin, Skeem, Novaco, \& Douglas, 2011).

Furthermore, there is a need to explore the differences, and similarities, between serious violent (SV) offenders. While literature has investigated perpetrators of homicide and other violent perpetrators (Soothill, Francis, Ackerley, \& Fligelstone, 2002), homicide and attempted murder criminals (Ganpat, Liem, van der Leun, \& Nieuwbeerta, 2014), and homicide and aggravated assault offenders (Smit, Bijleveld, Brouwers, Loeber, \& Nieuwbeerta, 2003), there is a scarcity in comparing various types of SV offenders. Ganpat and colleagues (2014) underlined their research as the first comparison of particular SV criminals and their criminal history, to their knowledge, with research urging for further explorations of SV offenders (Polaschek, 2006). In light of the arguments relating to the impact of gender differences on serious violence, research must determine to what extent SV offenders are a homogenous, or heterogeneous, set of perpetrators

There are reports of an increase in violent female criminality (e.g. Nicholls, Cruise, Greig, \& Hinz, 2015); a higher proportion of female offenders were arrested for violence against the person in 2015/16 (females: 38\%; males: 34\%; Ministry of Justice [MoJ], 2016). However, Thornton and colleagues (2012) highlighted the likelihood that statistics of violent crimes committed by female perpetrators are not an accurate reflection of actual rates of offending. Researchers (e.g. George, 1999, 2003; Simmons, Lehmann, Cobb, \& Fowler, 2005) proposed an explanation for this, as it is argued that more men faced immediate custody ( $83 \%)$ than women $(68 \%)$, with fines being more likely to be issued to females $(82 \%)$ than males $(65 \%$; MoJ, 2016). Furthermore, Kong and AuCoin (2008) noted how female offending could be somewhat undetected, due to the focus being drawn to the much larger male offender 


\section{DO FEMALE OFFENDERS DIFFER?}

population.

Yet, Trägårdh, Nilsson, Granath and Sturup (2016) stated, "less is known about female homicide offenders" (p.126). Thus, while there has been an increase in focus on female perpetrators over the past few years (Rettinger \& Andrews, 2010), many attempts to explore female criminality have focused on specific variables (Loucks \& Zamble, 1999), such as psychopathy, mental health and intimate partner violence (IPV). Yet, for a group of offenders referred to as a "unique and rapidly expanding population" (Nicholls et al., 2015, p.79), it is evident further explorations are necessary. When attention has turned to female perpetrators and investigated whether there are risk factors specific to the gender of the offender, empirical findings are consistently limited by small samples (Tracy, Wolfgang, \& Figlio, 1990). Not only is research into female offenders necessary to support the development of practitioner risk tools, it is also of importance to public welfare (Nicholls et al., 2015). Further research into risk factors of SV females would inform investigative practices, in addition to aiding in decision-making within court proceedings (West, Hatters, Friedman, \& Kim, 2011).

\subsection{Theoretical Approaches to Female Criminality}

In view of gender in theories of crime, concerns have been noted surrounding how effective theories, which are characteristically dominated by male offenders, can explain female perpetrators (McRobbie \& Garber, 2005; Steffensmeier \& Allan, 1996; Vold, Bernard, \& Snipes, 2002), due to the failure to factor in the gender gap in criminal behaviour (McRobbie \& Garber, 2005; Nwalozie, 2015). There are arguments that support the application of criminal theory to females (Hartjen \& Priyadarsini, 2003), such as claims surrounding the similarities in male and female offender's backgrounds, including poor education, unemployment, low socioeconomic status and social control (e.g. Chesney-Lind \& Shelden, 1992; Giordano, Cernkovich, \& Pugh, 1986; Steffensmeier \& Allan, 1995, 1996). Further, both males and females were more likely to engage in criminality when a romantic partner offended (Alarid, Burton, \& Cullen, 2000), yet Benda (2005) argued there was a greater negative impact on females. In addition, peer encouragement to participate in criminality was more pertinent for males (Simons, Stewart, Gordon, Conger, \& Elder, 2002) and deemed less influential to females (Mears, Ploeger, \& Warr, 1998). Thus, it is evident that a deeper theoretical understanding of female offenders is required; Chesney-Lind and Pasko (2013) argued the application of theory to female offenders was problematic, with Smart (2013) claiming that the "knowledge of the nature of female criminality is still in its 
DO FEMALE OFFENDERS DIFFER?

infancy" (p. 1). Although the current research does not investigate factors that provide the basis for theories of criminal behavior, such as peer groups, significant life events or socioeconomic status, it aims to conduct an exploratory analysis to obtain a clearer understanding of female offenders and thus make an initial effort to address this lack of understanding.

\subsection{Research on Female Offenders: Age}

Descriptive research of female offenders is limited as, for example, investigation of violent female offenders appears to include another aspect, such as a focus on IPV (e.g. Caman et al., 2016; Thornton et al., 2012), sexual homicide (Chan \& Frei, 2013), or psychotic disorders (e.g. Bennett, Ogloff, Mullen, \& Thomas, 2012). In regards to the onset age of violence, research reports this to be earlier in female offenders (e.g. Moffitt, Caspi, Rutter, \& Silva, 2001; Serbin \& Karp, 2004); in comparison to nonviolent perpetrators, violent females were reported to be significantly younger (Goldstein \& HigginsD’Alessandro, 2001; Pollock, Mullings, \& Crouch, 2006). Furthermore, Heidensohn and Silvestri (2012) highlighted that females typically peak in their offending in their mid-teens (Gelsthorpe, Sharpe, \& Roberts, 2007; Home Office, 2003). Yet, there are mixed reports in literature relating to the age of violent females, as there have also been reports of latetwenties (e.g. Bonta, Pang, \& Wallace-Capretta, 1995; Chan \& Frei, 2013; Murdoch, Vess, \& Ward, 2012; Thornton et al., 2012), with others reporting offenders to be in their thirties (e.g. Bennett et al., 2012; Pollock et al., 2006; Rettinger \& Andrews, 2010). Thus, comparing the average age of females is problematic due to the inconsistencies within literature. For example, the average age was noted at different points (e.g. during incarceration), with other instances not specifying when the age referred to. Additionally, the offenders are argued to be from "unrepresentative subpopulations" (Loucks \& Zamble, 1994, p. 22), thus making associations difficult.

\subsection{Research on Female Offenders: Criminal History}

Women who have engaged in violence have been reported to have an offending history (Busch \& Rosenberg, 2004; Moffitt et al., 2001). Statistics provided by MoJ (2016) reported that $16 \%$ of females, who were sentenced for an indictable offence, had no previous cautions or convictions, with $31 \%$ of female offenders having $15+$ previous convictions or cautions, suggesting that a large proportion of female perpetrators do not have a substantial criminal history (Forsyth, Wooddell, \& Evans, 2001; Rossegger et al., 2009; Yourstone, Lindholm, \& 


\section{DO FEMALE OFFENDERS DIFFER?}

Kristiansson, 2008). However, it is important to highlight that the proportion of females, with $15+$ previous convictions or cautions, has "risen to a greater extent" (p. 96) than males over the last decade (MoJ, 2016). In terms of the types of previous convictions, research conducted by Thornton and colleagues (2012) identified "all types of offending behaviour" (p. 1412) in a female sample, including IPV, general violence and other thefts (e.g. shoplifting). This is further evident in the prior offences committed by females in additional research, including crimes relating to public order (Alder \& Worrall, 2004; McKeown, 2010), drugs, property, theft (e.g. McKeown, 2010) and general aggression (Moffitt et al., 2001). Pollock and colleagues (2006), in their assessment of violent and nonviolent female prisoners, stated that offenders, currently convicted of drug and property offences, had reported committing violent offences in the previous year. Self-report measures found that violent, in comparison to non-violent, offenders had a criminal history that included theft of vehicle, weapons, handling, gang membership, shoplifting and damaged property. Similarly, MoJ (2016) reported that violence against the person, theft and drug crimes were the most common offences for females to be convicted of.

\subsection{Summary}

Explorations between female SV and non-SV perpetrators are sparse in literature (e.g. Pollock et al., 2006). While female offenders are beginning to gain focus (Rettinger \& Andrews, 2010), earlier research has been criticised for the lack of attention towards gender and criminality (Shaw, 1994; Soothill et al., 2002), with this stressing the need to explore violent, and nonviolent, reoffending in female perpetrators. Furthermore, there is still a requirement for an in-depth understanding of female offenders to assist in crime prevention strategies and to determine which offenders are at risk of reoffending (Kong \& AuCoin, 2008); de Vogel and colleagues (2014) argued that empirical investigations of femalecentered risk assessment are overshadowed by the magnitude of the perceived problem of male SV offending. Regardless, research into female offending reports mixed findings. Moreover, theories developed to explain female offending fail to explain the variety of all offences committed (e.g. assault or murder; Loucks \& Zamble, 1999). Thus, the aim was to investigate factors of SV female offenders to achieve a further understanding of this offending group. In particular, this research aimed to determine if SV females differ to their non-SV counterparts (the control sample).

\subsection{Aims of the Study}


DO FEMALE OFFENDERS DIFFER?

i. To develop the existing understanding of female offenders by exploring descriptive and criminal history information;

ii. To compare SV female offenders to a control group, of non-SV female perpetrators, to identify differences in the age at the first offence in the dataset, the frequency of offending and the presence of crime types in their criminal history.

\section{Methodology}

\subsection{Sample: SV Female Offenders}

In the current research, a SV offence was recorded as grievous bodily harm (GBH), attempted murder or homicide. The dataset provided by Devon and Cornwall Police Force ranged from April 2001 to March 2011. Therefore, SV offences were identified from a specified period of time (April 2005 to March 2011) to ensure that there would be a reasonable amount of time in the remaining dataset for previous offences to be traced. Between April 2005 and March 2011, in the Devon and Cornwall area, 206 SV female offenders were classified as committing a SV offence. Offending details known to the police were recorded, as was the age of offenders at the time of committing the target offence (attempted murder, GBH or homicide) and at the time of the first offence; it is crucial to note that this is the first offence that is recorded within the database (from April 2001) and therefore may not be the first offence committed by the offender. Nevertheless, there is a good follow-up period for all offenders, as this would be a minimum of 4 years; for example, for an offender who committed a SV offence in April 2005, their criminal history dating back to April 2001 would be available.

\subsection{Sample: Control Offenders (Non-SV)}

Soothill and colleagues (2002) stated the importance of determining the difference between serious and general criminals; in order to do this, a control group must be formed, with a suggestion that three controls per violent offender is appropriate. Additionally, Soothill et al. (2002) highlighted the need to include offenders who are still 'active'; therefore, offenders in the control group will have committed a non-SV offence within the same calendar year as SV offenders. The control sample was constructed to enable comparisons to be made with the SV sample; as the control group consisted of offenders with convictions for non-, or lesser-, violent crimes, it assisted in identifying instances of the heterogeneity, or homogeneity, of perpetrators. Therefore, an essential criterion for the 


\section{DO FEMALE OFFENDERS DIFFER?}

control sample was that members within this sample did not have any convictions for SV offences, between April 2001 and March 2011.

Therefore, offenders within this sample had not committed a SV offence between April 2001 and March 2011, as recorded by Devon and Cornwall police. The remaining cases were then matched according to age and year of the target offence of criminals in the SV group. Control offenders were only required for SV offenders with an offending history $(n=149$; Soothill et al., 2002), resulting in a comparison sample of 447 non-SV female offenders.

\subsection{Design}

The current research proposed to conduct a retrospective analysis, where the individuals within the sample are examined through the offender characteristic of age and criminal history information (offending frequency and crime types) to detect differences between female SV and control offenders. Age at the target offence was not investigated due to SV and control offenders being matched on this criterion.

\subsection{Procedure}

The age of female perpetrators and the criminal history of each offender were explored. Each offender was coded, in terms of age at the first recorded offence ${ }^{1}$ in the dataset, the frequency of offending and the types of crimes committed by the offenders, according to four crime categorisation schemes. Almost 250 types of crime were recorded within the dataset; the offences from the police dataset were grouped according to a number of offence categorisation schemes. Criminal histories were examined according to four, eight, 15 and 24 crime categorisation schemes (see Table 1). The use of four categories was based on previous research (e.g. Harris, Smallbone, Dennison, \& Knight, 2009), with eight categories drawn from the more general offence categories presented in the police data. As used by Harris and colleagues (2009), the present research used the current Australian and New Zealand Standard Offence Classification (ANZSOC; Pink, 2011); this identified 16 categories, however one category was not applicable to the UK dataset (Dangerous or negligent acts endangering persons) and therefore 15 categories remained. The 24 categories were identified from those used by the Home Office (2012), with consideration of the 38 offence groups used by Francis, Liu and Soothill (2008). It is important to highlight that there are categories present in the 15 (serious violent), and 24 (attempted murder, GBH, homicide), offence

\footnotetext{
${ }^{1}$ Since April 2001
} 
DO FEMALE OFFENDERS DIFFER?

categorisation schemes that are not applicable to the control sample, as offenders within the control sample, by definition, did not contain such offences in their criminal history.

\subsection{Statistical Analyses}

The variables of age at first offence within the database and the frequency of offending were assessed for normal distribution; each variable reported a significant KolmogorovSmirnov statistic, thus violating the assumption of normality. Moreover, the histograms depicted a skewed distribution. Therefore, Mann-Whitney U tests were utilised to explore the differences between the SV and control female samples. Descriptive analyses investigate the previous offending history of SV offenders to add to the existing, yet somewhat limited, understanding of SV females and the nature of their criminality. Statistical analyses explored whether there were differences in the SV and the control samples, in terms of:

i. The age at the first offence in the dataset and the frequency of offending (Mann Whitney U analysis);

ii. The presence of offence types (2x2 Chi-square analysis).

\section{Results}

\subsection{Age}

3.1.1 SV offenders. In terms of the age of offenders at the time of the first offence recorded within the database (i.e. post 2001), the ages ranged from nine to 53 years $(n=149)$. The median age recorded was 19.00, with an average age of 22.92 years $(S D=10.01)$. The age of offenders, at the time of committing the target offence, ranged from 13 to 62 years. The mean age of females was 27.00 years $(S D=10.38)$, with a median of 24.00 years. When only females with previous convictions were included, the median was 24.00 years, with a range from 13 to 60 years $(M=27.07, S D=10.15)$.

3.1.2 Control offenders. When the target offence was committed, the average age of the control group was 26.99 years old $(S D=9.94)$ and the median age was 24.00 years, with the youngest offender recorded as 13 years and the oldest being 60 years old $(n=447)$. The mean age of female controls, at the time of the first offence that was recorded in the database, was 22.56 years $(S D=9.47)$ and the median age was 20.00 years.

3.1.3 A comparison of SV female and control offenders. SV offenders with previous convictions $(n=149)$ and control offenders $(n=447)$ were compared in relation to the age at the time of committing the first offence; no significant differences were found $(p>.05)$. 
DO FEMALE OFFENDERS DIFFER?

\subsection{Frequency of Offending}

3.2.1 SV offenders. This section of the analysis considered only those offenders with previous convictions; 57 (27.7\%) SV females had not previously been charged with an offence. Thus, $72.3 \%(n=149)$ of offenders had one or more recorded convictions. From the analysis of the 149 females, the number of previous convictions (post 2001) ranged from one to 50 ; the average number of prior offences was $5.81(S D=6.79)$, with a median score of 4 . The most common number of previous convictions was one $(n=40)$, followed by two $(n=$ $16)$, three $(n=15)$ and five offences $(n=14)$, with one perpetrator being held responsible for 50 prior crimes.

3.2.2 Control offenders. Within this sample, the number of previous convictions stretched from 1 to 154 , with a median score of 3 and an average of $7.22(S D=12.35)$. It is important to note here that this sample was randomly selected from all appropriate matches that had been highlighted and so this is a fair representation of all non-SV offenders within the dataset.

\subsubsection{A comparison of $\mathrm{SV}$ female and control offenders: frequency of offending. No} significant differences were found between the sample of SV offenders, compared with the control sample, in terms of the number of previous convictions $(p>0.05)$.

\subsection{Types of Previous Convictions}

3.3.1 SV offenders. Table 2 shows the types of previous convictions committed by SV offenders. Of the 149 perpetrators with prior offences, across each of the categorisation schemes, sexual offences were not recorded; in addition, no crimes of justice (15 categories) or abduction ( 24 categories) were noted. The largest proportions of female criminality were identified within the violent offences (four categories: $75.8 \%$ violent; eight categories: $74.5 \%$ violent; 15 categories: $65.8 \%$ cause injury; 24 categories: $53.0 \% \mathrm{ABH})$. Fewest SV offenders were reported to have previously committed burglary-related offences ( 8 categories: $9.4 \%$ burglary/robbery; 15 categories: $6.7 \%$ burglary, $4.0 \%$ robbery; 24 categories: $4.0 \%$ domestic burglary, $2.7 \%$ non-domestic burglary) and theft-related crimes (15 categories: $6.0 \%$ fraud; 24 categories: $6.0 \%$ fraud and forgery, $0.7 \%$ theft from vehicle, $0.7 \%$ vehicle interference), and were unlikely to have been charged for a weapons offence (15 categories: $3.4 \%$ weapons; 24 categories: $3.4 \%$ possession of weapon).

3.3.2 Control offenders. The types of previous convictions committed by the control sample are shown in Table 2. All females within the control sample had a previous conviction recorded. Other (4 categories: $76.7 \%$ other; 8 categories: $39.1 \%$ non-notifiable; 15 


\section{DO FEMALE OFFENDERS DIFFER?}

categories: $35.1 \%$ miscellaneous; 24 categories: $37.9 \%$ criminal damage), violent (4 categories: $64.3 \%$ violent; 8 categories: $63.7 \%$ violent; 15 categories: 51.6\% cause injury; 24 categories: $39.2 \% \mathrm{ABH}, 27.0 \%$ assault) and theft (4 categories: $52.3 \%$ property; 8 categories: $48.3 \%$ theft/handling; 15 categories: $48.6 \%$ theft; 24 categories: $43.5 \%$ other theft) crimes were frequently observed in the control sample. Within this sample, fewest offences were recorded in terms of sexual crimes (1.8\% across all four crime categorisation schemes).

3.3.3. A comparison of $S V$ female and control offenders: types of crime. Chi-square analyses were conducted to investigate the differences in the types of crimes committed in the criminal histories of female SV, compared to control offenders. When the four crimes categorisation scheme was applied, significant differences between the SV and control groups were observed (see Table 3); violent offences were twice as likely to appear in the criminal histories of SV females compared to their non-SV counterparts, with the control sample being at an increased likelihood of having previously committed a property offence.

In relation to the eight offences categorisation scheme (Table 4), SV female offenders were found to have double the probability of having a previous conviction for violence, whilst the control offenders had a significantly higher likelihood of committing theft/handling crimes.

When comparing offender criminal histories in regards to the 15 crimes categorisation scheme (see Table 5), SV females were three times more likely to previously commit public order offences, and almost twice as likely to have a previous conviction for cause injury, compared to the control sample. Yet, controls were more likely to have a prior offence of theft, when compared to female SV offenders.

In the comparison of offences within the 24 crimes categorisation scheme (see Table 6), SV females were more likely to have committed ABH or assault, than controls. On the other hand, those in the control sample had an increased likelihood of having previously committed other theft, when compared to their SV counterparts. No other statistically significant differences were detected $(p>.05)$. Small and medium effect sizes were reported.

\section{Discussion}

Female offenders have been relatively ignored in previous research (e.g. Bonta et al., 1995; Loucks \& Zamble, 1999; Nicholls et al., 2015; Soothill et al., 2002; Thornton et al., 2012). Thus, with the aim of developing the current awareness of female criminality, this study adopted a retrospective approach to explore such SV offenders and their criminal histories. The current research utilised data that ranged across a 10-year period to compare 


\section{DO FEMALE OFFENDERS DIFFER?}

the offending histories of $149 \mathrm{SV}$ female offenders to 447 non-SV female offenders (the control sample). This enabled a comparison to be made, to determine if female SV offenders differed to non-SV perpetrators.

Offenders from both samples were compared on age at the first offence that was recorded in the database; no significant differences were detected between SV and control females. Nonetheless, the descriptive data adds to the sparse literature of SV female perpetrators (Nicholls et al., 2015). While it is difficult to make comparisons with existing research, due to the differences in when the age of the offender was recorded (e.g. Rettinger \& Andrews [2010] recorded the age of the offenders at the time the survey was completed, while the offender was incarcerated) or the specificity of offences (e.g. intimate partner homicide, Caman et al., 2016), this research will assist in painting a clearer picture of SV female offenders. SV female offenders, in the current research, generally reflected the ages reported for SV perpetrators in previous literature, in terms of both the age at the first offence and the age at the time of committing the SV crime (e.g. Murdoch et al., 2012; Thornton et al., 2012). In regards to previous convictions, $72.3 \%$ of the SV sample $(n=149)$ had one or more offences recorded in their criminal history, comparable to the $68.2 \%$ of Rettinger and Andrews (2010) violent female sample. The remaining 27.7\% of the SV female offenders had not been held responsible for a prior crime, during the given time frame. The frequency of offending did not differ significantly between the SV and control samples.

Across the four crime categorisation schemes, SV females were more likely to have a prior conviction for violent offences, compared with perpetrators in the control sample, thus lending support to previous literature that has stated the presence of general violence and aggression in violent female offender's criminal histories (e.g. Moffitt et al., 2001; Pollock et al., 2006; Thornton et al., 2012). Moreover, robbery has been argued to be less likely to appear in the prior offences of females (Pollock et al., 2006), with the current research reporting $3.4 \%$ of the SV sample having committed robbery. Whereas, theft-related crimes have been identified in the offending history of violent female perpetrators (e.g. Pollock et al., 2006), yet the current research identified such offences to be more likely associated with females in the control sample. This highlights the dissimilarities apparent between SV and non-SV female offenders. Further, earlier research reported criminal damage was likely to appear in the criminal histories of SV offenders (Howard \& Dixon, 2013; Pollock et al., 2006; Thornton et al., 2012); yet, although not significantly different, a higher proportion of non-SV females had convictions for criminal damage 


\section{DO FEMALE OFFENDERS DIFFER?}

Interestingly, the offence of kidnapping was not recorded in the SV or control groups; in research by Soothill and colleagues (2002), kidnapping was found in male offenders who went on to commit murder. Liu, Francis and Soothill (2008) delved into this topic of research, in consideration of gender, and found that 282 offenders in the sample, of which 14 were females, had a conviction of kidnapping. Yet again, other research did not record any offences of abduction in the sample (Rossegger et al., 2009). Consequently, the findings are mixed and would benefit from further insight.

\subsection{Implications}

Within the general area of forensic psychology, a number of significant relationships have emerged between researchers and practitioners; this has developed into a strong partnership that benefits both parties, resulting in a demand for evidence-based research, with outcomes that may have a subsequent impact on operational practice in the community (Taylor, Snook, Bennell, \& Porter, 2015). For example, Wermink and colleagues (2016) highlighted the use of empirical research to inform the sentencing of offenders, in addition to other judicial and practical decisions, such as the type of action, treatment, community management and supervision needs (Craig, Beech, \& Cortoni, 2013; Hilton, Harris, \& Rice, 2010; Soothill, Francis, \& Liu, 2008). What is more, Zagar, Grove and Busch (2013) reported the need for policies to review violence due to the impact this has, in terms of the costs to society and increasing demands on the prison system. As a result of the recent economic crisis and cuts to the police force in the UK, it is necessary to adapt, develop and implement cost-effective approaches. In addition, the assessment of risk by practitioners is essential (Hollin, 2009), as a practitioner must make decisions about offenders that may lead to the public being at risk if the practitioner was to make the wrong decision. Furthermore, the predictors for further criminality may differ according to the offender and the crime that they commit, as if offenders are not a homogenous group they would require different risk assessment tools (Hollin, 2009). There are practical implications of differentiating between violent and nonviolent offenders; the presence of differences between these perpetrators would suggest the allocation of resources should therefore differ according to the type of offender and the subsequent risk of harm to society (Lai, Zeng, \& Chu, 2015). Thus, the current findings lend insight into SV female offenders and their criminal histories, and how they may - or may not - differ from non-SV female perpetrators.

4.1.1 Theoretical implications. Explorations into female offenders is limited, with a failure to agree if theories of crime can be applied to both sexes (e.g. Alarid et al., 2000; 


\section{DO FEMALE OFFENDERS DIFFER?}

Benda, 2005; Giordano, Cernkovich, \& Holland, 2003; Kruttschnitt, Uggen, \& Shelton, 2000). While further details (e.g. peers, relationships, motivations) would be necessary to comment on specific theories of crime, the current research suggests that theory must consider both the gender of the offender and the type of crimes they commit, and thus should not treat perpetrators as a homogenous group.

4.1.2 Practical implications. As noted, in terms of differences between violent and nonviolent criminals, this has implications for the criminal justice system, such as allocating resources appropriately to those at most risk of harm to society (Lai et al., 2015).

Additionally, Soothill and colleagues (2002) stressed the value of understanding criminal careers for those within the criminal justice system; in particular, offender characteristics, criminal history and the severity of the crime have been argued to have an impact on this decision-making (Spohn, 2000; Wermink et al., 2016). Violent offending was recorded in this female sample, with differences found between women in the SV and control samples; this enhances the current claims for more attention to be turned to females in research (e.g. Nicholls et al., 2015). Moreover, as established earlier, decisions relating to the likes of sentencing and parole are often influenced by the defendant's gender (e.g. Tillyer, Hartley, \& Ward, 2015); thus, the current findings go some way in informing and demonstrating the criminality displayed by females (e.g. West et al., 2011).

In consideration of the crime categorisation schemes, applying each set of crime categories detected differences and relationships within the data. Thus, this questions whether specific offence categories would be beneficial to research and practitioners, as utilising broader crime categories risks hiding important details. Harris and colleagues (2009) recommended using fewer offence categories arguing it may be more advantageous in terms of methodology. Yet this could be argued to be undesirable due to the risk of grouping offenders who would otherwise be categorised differently, if more specific crime types were used. Similarly, Youngs, Ioannou and Eagles (2016) considered the limitations of using broad crime categories, warning that a perpetrator's criminality could be oversimplified and thus not give an accurate representation of their offending. On the other hand, a limitation of using too many categories is the inclusion of minor crime categories, such as traffic offences, which do not demonstrate serious offences (Horning, Salfati, \& Crawford, 2010) and could therefore be argued to be meaningless; similarly, Brame, Mulvey, Piquero and Schubert (2014) questioned the use of 'other' and 'miscellaneous' categories. Adding support for the need for consistency amongst research, Nieuwbeerta, Blokland, Piquero and Sweeten (2011) noted difficulties in making comparisons amongst research as a result of the different 


\section{DO FEMALE OFFENDERS DIFFER?}

categories used. What is more, considering the use of categories has importance implications to practitioners (e.g. Loeber \& Ahonen, 2014).

\subsection{Limitations}

Access to police data is valuable to research; the use of such data provides researchers with a way to investigate a variety of forensic topics (Alison, Snook, \& Stein, 2001). However, police data is not without its limitations. The information documented was for police investigations (Alison et al., 2001), where the goal is to achieve a conviction of the guilty offender(s), as opposed to research purposes (Almond, McManus, \& Ward, 2013; Canter \& Alison, 2003) and as such the research design and methodology was not a primary consideration (i.e. other details not considered to be relevant to conviction might have been overlooked). Moreover, archival data may differ, depending on the differences in "recordkeeping policies and practices" (Arthur et al., 2001, p. 9), which would be applicable both on an individual basis (individual differences in recording details from one case to another) and also as a police force (Alison et al., 2001). Further, an additional limitation of this data is, of course, that the data were provided by a single police force; thus, the offenders may be representative of that area only (Devon and Cornwall) and may not, therefore, reflect offenders in other areas. This is not unusual, however; for example, Cook, Ludwig and Braga (2005) faced similar restrictions. The location of the police force must also be considered; the present data were from a force based in a rural area and so the findings may differ from those using samples drawn from urban locations

Another limitation of the current data is that the follow-up period within the data were limited from April 2001; consequently, the data were likely to represent only a snapshot of the offender's criminal history. Therefore, any offences recorded before this have not been included and it cannot be guaranteed that the first offence recorded in the dataset was an offender's first crime in their criminal history for perpetrators in both the SV and control samples. This has implications for the age of the offender at the first offence, as it cannot be guaranteed that this is the offender's first offence committed. Similarly, it cannot be ascertained whether SV offenders had committed additional, or more serious, SV crimes other than those recorded in the dataset. This has a number of implications; firstly, those SV offenders who have committed the same SV offence previously, and could thus be argued to be serial offenders, may differ from those who have committed an SV crime once (see DeLisi \& Scherer, 2006; Wright, Pratt, \& DeLisi, 2008). Nevertheless, perpetrators in Ganpat et al.'s (2014) attempted and completed murder samples held previous convictions for attempted 


\section{DO FEMALE OFFENDERS DIFFER?}

and/or complete murders; the researchers noted that the purpose of the research was to explore SV criminal histories, regardless of whether offenders had such prior offences. Ganpat et al. (2014) analysed the data containing those with SV previous offences and also without, concluding that this did not have any great differences in their findings. Similarly, it cannot be determined whether any offenders in the control sample had a SV crime in their criminal history prior to 2001. For the control sample, this would be problematic based on the criteria for their inclusion; yet, other research that has used matched-case controls cannot certify that the control sample did not contain offenders with SV previous convictions that were unknown to the police (e.g. Clarke et al., 2016; Soothill et al., 2002), and thus it is evident that this is a limitation associated with the type of data used.

There are also issues in relating the findings with literature; for example, some research considers the impact of additional factors, such as IPV (Thornton et al., 2012), with descriptive information (such as age) being recorded at different stages and varying samples being employed (e.g. prison vs. student population). Additionally, a weakness of the sample is the small proportion of SV female offenders with previous convictions $(n=149)$. However, research has generally noted the shortage of research on SV offences committed by female offenders, due to low murder arrest rates (Chan \& Frei, 2013) and small proportions of SV females (e.g. Rossegger et al. [2009] used a sample of only six female homicide perpetrators). In comparison with previous research, this investigation has a relatively large sample size for a criminal female population; other research has utilised sample sizes that have varied from 16 to 55 to 202 female offenders (Rossegger et al., 2009; Bennett et al., 2012; Chan \& Frei, 2013, respectively).

It can be noted also that the current research selected SV offenders of attempted murder, homicide and GBH, and is, therefore, restricted in its application to other SV offences (e.g. Ganpat et al., 2014). What is more, the findings may be confounded by the differing types of $\mathrm{SV}$ crime; research has reported differences in specific SV offences, such as interpersonal violence, filicide and accidental homicide, in terms of the motivations, offender characteristics and circumstances (e.g. Bourget \& Bradford, 1990; Roberts, Zgoba, \& Shahidullah, 2007; Straus, 2007). Moreover, as pointed out by Vaughn, DeLisi, Beaver and Howard (2008), there is a lack of standardisation in the definition of homicide used in research, as many group different types of homicides together. Thus, such different offenders are often categorised under one homogenous group.

However, the strengths of this research must also be noted. As the review of the existing literature shows, there have been limitations when making comparisons because of 


\section{DO FEMALE OFFENDERS DIFFER?}

inconsistencies in methodological practice. Firstly, findings that are produced without the use of a control sample limit the extent to which they can be claimed to be characteristics of those in the sample (e.g. Craissati \& Sindall, 2009). Clearly the use of a matched-case control sample is an advantage to the present research. Additionally, Ganpat and colleagues (2014) reported the investigation of lethal and non-lethal violent offenders as the first to compare a sample of specifically SV offenders, focussing on the criminal history. The current exploration, therefore, greatly adds to this sparse area of empirical research, particularly in terms of female perpetrators.

\subsection{Conclusion}

This research explored the age and offending history information of $206 \mathrm{SV}$ offenders ( $n=149$ with previous convictions), with a control sample of 447 perpetrators. The purpose of the research was to identify differences between females in the SV and control samples. As a result of using a suitable control sample, the findings assist in determining how SV offenders may differ from other offenders. Therefore, SV female offenders do demonstrate differences in the types of offences they commit, prior to committing an SV offence, when compared to non-SV offenders. This has potential implications for crime prevention strategies and the identification of those offenders who are at risk of future SV offending, as the findings add to the growing literature about the differences in female, particularly SV, perpetrators. 


\section{DO FEMALE OFFENDERS DIFFER?}

\section{References}

Alarid, L., Burton, V., \& Cullen, F. (2000). Gender and crime among felony offenders: Assessing the generality of social control and differential association theories. Journal of Research in Crime and Delinquency, 32, 171-199.

Alder, C., \& Worrall, A. (2004). Girls' violence: Myths and realities. Albany: State University of New York Press.

Alison, L., Snook, B., \& Stein, K. (2001). Unobstrusive measurement: Using police information for forensic research. Qualitative Research, 1, 241-254.

Almond, L., McManus, M., \& Ward, L. (2013). Male-on-male sexual assaults: An analysis of crime scene actions. Journal of Interpersonal Violence, 29 (7), 1279 - 1296.

Andrews, D. A., \& Dowden, C. (2006). Risk principle of case classification in correctional treatment. International Journal of Offender Therapy and Comparative Criminology, 50(1), 88-100. doi: 10.1177/0306624X05282556

Arthur Jr. W., Tubre, T., Day, E. A., Sheehan, M. K., Sanchez-Ku, M. L., Paul, D., ... Archuleta, K. (2001). Motor vehicle crash involvement and moving violations: convergence of self-report and archival data. Human Factors, 43 (1), 1-11.

Benda, B. B. (2005). Gender differences in life-course theory of recidivism: A survival analysis. International Journal of Offender Therapy and Comparative Criminology, 49(3), 325-342.

Bennett, D., Ogloff, J., Mullen, P., \& Thomas, S. (2012). A study of psychotic disorders among female homicide offenders. Psychology, Crime and Law, 18 (3), 231-243.

Bonta, J., Pang, B., \& Wallace-Capretta, S. (1995). Predictors of recidivism among incarcerated female offenders. The Prison Journal, 75, 277-294.

Bourget, D., \& Bradford, J.M. (1990). Homicidal parents. The Canadian Journal of Psychiatry, $35,233-238$.

Brame R., Mulvey E. P., Piquero A. R., Schubert C. A. (2014). Assessing the nature and mix of 


\section{DO FEMALE OFFENDERS DIFFER?}

offences among serious adolescent offenders. Criminal Behaviour and Mental Health, 24, 254-264. doi:10.1002/cbm. 1936

Busch, A., \& Rosenberg, M. (2004). Comparing women and men arrested for domestic violence: A preliminary report. Journal of Family Violence, 19, 49-58.

Caman, S., Howner, K., Kristiansson, M., \& Sturup, J. (2016). Differentiating male and female intimate partner homicide perpetrators: A study of social, criminological and clinical factors. International Journal of Forensic Mental Health, 15(1), 26-34. doi:

$10.1080 / 14999013.2015 .1134723$

Campbell, A. (1993). Men, women and aggression. New York, USA: Basic Books.

Canter, D. V., \& Alison, L. J. (2003). Converting evidence into data: The use of law enforcement archives as unobtrusive measurement. The Qualitative Report, 8, 151-176.

Chan, H. C., \& Frei, A. (2013). Female sexual homicide offenders: An examination of an underresearched offender population. Homicide Studies, 17 (1), 96-118.

Chesney-Lind, M., \& Pasko, L. (2013). The female offender: Girls, women and crime. Thousand Oaks, CA: Sage Publications, Inc.

Chesney-Lind, M., \& Shelden, R. (1992). Girls, delinquency, and juvenile justice. Pacific Grove, CA: Brooks/Cole.

Clarke, M., McCarthy, L., Huband, N., Davies, S., Hollin, C., \& Duggan, C. (2016). The characteristics and course after discharge of mentally disordered homicide and non-homicide offenders. Criminology and Penology, 20(1), 80-97. doi: 10.1177/1088767915570312

Cook, P. J., Ludwig, J., \& Braga, A. A. (2005). Criminal records of homicide offenders. Journal of the American Medical Association, 294(5), 598-601.

Craig, L. A., Beech, A. R., \& Cortoni, F. (2013). What works in assessing risk in sexual and violent offenders. In L. E. Craig, L. Dixon \& T. A. Gannon (Eds.), What works in offender rehabilitation: An evidence-based approach to assessment and treatment (pp. 94-114). 


\section{DO FEMALE OFFENDERS DIFFER?}

Chichester: Wiley.

Craissati, J., \& Sindall, O. (2009). Serious further offences: An exploration of risk and typologies. Probation Journal, 56, 9-27.

Crown Prosecution Service (n.d). Legal guidance. [Online] Available from http://www.cps.gov.uk/legal/. [Accessed: 26 ${ }^{\text {th }}$ July 2015].

DeLisi, M., \& Scherer, A. M. (2006). Multiple homicide offenders: Offence characteristics, social correlates and criminal careers. Criminal Justice and Behaviour, 33(3), 367-391. doi: $10.1177 / 0093854806286193$

De Vogel, V., De Vries Robbé, M., Van Kalmthout, W., \& Place, C. (2014). Female additional manual: Additional guidelines to the HCR-20 for assessing risk for violence in women. Utrecht: Van Der Hoeven Kliniek.

Dvoskin, J. A., Skeem, J. L., Novaco, R. W., \& Douglas, K. S. (2011). What if psychology redesigned the criminal justice system? In J. A. Dvoskin, J. L. Skeem, R. W. Novaco, \& K. S. Douglas (Eds.), Using social science to reduce violent offending. New York, NY: Oxford University Press.

Francis, B., Liu, J., \& Soothill, K. (2008). Using the offenders index to investigate patterns of offending. Paper Given at the 13th Government Statistical Service Methodology Conference, London, England.

Forsyth, C. J., Wooddell, G., \& Evans, R. D. (2001). Predicting symmetry in female/male crime rates. Journal of Police and Criminal Psychology, 16 (2), 1-9.

Ganpat, S. M., Liem, M., van der Leun, J., \& Nieuwbeerta, P. (2014). The influence of criminal history on the likelihood of committing lethal versus nonlethal violence. Homicide Studies, 18(2), 221-240. doi: $10.1177 / 1088767912466082$

Gelsthorpe, L., Sharpe, G., \& Roberts, J. (2007). Provision for Women Offenders in the Community. London: Fawcett Society. 


\section{DO FEMALE OFFENDERS DIFFER?}

George, M. (1999). A victimization survey of female-perpetrated assaults in the united kingdom. Aggressive Behavior, 25, 67-79.

George, M. (2003). Invisible touch. Aggression and Violent Behavior, 8, 23-60.

Giordano, P., Cernkovich, S., \& Pugh, M. (1986). Friendships and delinquency. American Journal of Sociology, 91, 1170-1203.

Giordano, P., Cernkovich, S. A., \& Holland, D. D. (2003). Changes in friendship relations over the life course: Implications for desistance from crime. Criminology, 41(2), 293-328.

Goldstein, H., \& Higgins-D’Alessandro, A. (2001). Empathy and attachment in relation to violent vs. non-violent offense history among jail inmates. Journal of Offender Rehabilitation, 32, 31-53.

Harris, D. A., Smallbone, S., Dennison, S., \& Knight, R. A. (2009). Specialisation and versatility in sexual offenders referred for civil commitment. Journal of Criminal Justice, 37, 37-44.

Hartjen, C. A., \& Priyadarsini, S. (2003). Gender, peers, and delinquency: A study of boys and girls in rural France. Youth \& Society, 34, 387-414.

Havens, J. F., Ford, J., Grasso, D., \& Marr, M. (2012). Opening Pandora’s Box: The importance of trauma identification and intervention in hospitalised and incarcerated adolescent populations. Adolescent Psychiatry, 2(4), 309-312.

Heidensohn, F., \& Silvestri, M. (2012). Gender and crime. In M. Maguire, R. Morgan \& R. Reiner (Eds.), The Oxford Handbook of Criminology (pp. 336-369). Oxford: Oxford University Press.

Heilbrun, K., DeMatteo, D., Marczyk, G. R., \& Goldstein, A.M. (2008). Standards of practice and care in forensic mental health assessment: Legal, professional, and principles-based considerations. Psychology, Public Policy and Law, 14(1), 1-26.

Hilton, N. Z., Harris, G. T., \& Rice, M. E. (2010). Risk assessment for domestically violent men: Tools for criminal justice, offender intervention, and victim services. Washington, DC: 


\section{DO FEMALE OFFENDERS DIFFER?}

American Psychological Association.

Hollin, C. (2009). Treatment manuals: The good, the bad and the useful. Journal of Sexual Aggression, 15(2), 133-137.

Home Office (2003). Statistics on women and the criminal justice system, section 95 report. London: Home Office.

Home Office (2011). User guide to home office crime statistics. London: Home Office Statistics. Available from:

https://www.gov.uk/government/uploads/system/uploads/attachment_data/file/116226/userguide-crime-statistics.pdf. [Accessed 26th July 2015].

Home Office (2012). Consultation on changes to recorded crime classifications and categories. London: Home Office.

Horning, A. M., Salfati, C. G., \& Crawford, K. (2010). Prior crime specialisation and its relationship to homicide crime scene behaviour type. Homicide Studies, 14(4), 377-399.

Howard, P. D., \& Dixon, L. (2013). Identifying change in the likelihood of violent recidivism: Causal dynamic risk factors in the OASYS violence predictor. Law and Human Behavior, 37, 163-174.

Kong, R., \& AuCoin, K. (2008). Female offenders in Canada (Report No. 85-002-Xie, Vol. 28, No. 1). Ottawa, On: Statistics Canada.

Kruttschnitt, C., Uggen, C., \& Shelton, K. (2000). Predictors of desistance among sex offenders: The interaction of formal and informal social controls. Justice Quarterly, 17(1), 61-88.

Lai, V., Zeng, G., \& Chu, C. M. (2015). Violent and nonviolent youth offenders: Preliminary evidence on group subtypes. Youth Violence and Juvenile Justice, 1-17. doi: $10.1177 / 1541204015615193$

Leschied, A. W. (2011). The treatment of incarcerated mentally disordered women offenders: A synthesis of current research. Ottawa, ON: Public Safety Canada. 


\section{DO FEMALE OFFENDERS DIFFER?}

Liu, J., Francis, B., \& Soothill, K. (2008). Kidnapping offenders: Their risk of escalation to repeat offending and other serious crime. Journal of Forensic Psychiatry and Psychology, 19, 164-179.

Loeber, R., \& Ahonen, L. (2014). What are the policy implications of our knowledge on serious, violent, and chronic offenders? Criminology and Public Policy, 13(1), 117-125. doi: $10.1111 / 1745-9133.12072$

Loucks, A.D., \& Zamble, E. (1994). Some comparisons of female and male serious offenders. Forum on Corrections Research, 6 (1), 22-25.

Loucks, A., \& Zamble, E. (1999). Predictors in recidivism in serious female offenders: Canada searches for predictors common to both men and women. Corrections Today, 61 (1), 26-32.

McKeown, A. (2010). Female offenders: Assessment of risk in forensic settings. Aggression and Violent Behavior, 15, 422-429.

McRobbie, A., \& Garber, J., (2005). Girls and Subcultures [1977]. In K. Gelder (Ed.), The subcultures reader ( $2^{\text {nd }}$ ed., pp. 105-112). London: Routledge.

Mears, D. P., Ploeger, M., \& Warr, M. (1998). Explaining the gender gap in delinquency: Peer influence and moral evaluations of behaviour. Journal of Research in Crime and Delinquency, 35, 251- 266.

Ministry of Justice (2016). Statistics on Women and the Criminal Justice System 2015. Retrieved from https://www.gov.uk/government/uploads/system/uploads/attachment_data/file/572043/wome $\underline{\text { n-and-the-criminal-justice-system-statistics-2015.pdf }}$

Moffitt, T. E., Caspi, A., Rutter, M., \& Silva, P. A. (2001). Sex differences in antisocial behavior: Conduct disorder, delinquency, and violence in the Dunedin longitudinal study. Cambridge, UK: Cambridge University Press. 


\section{DO FEMALE OFFENDERS DIFFER?}

Murdoch, S., Vess, J., \& Ward, T. (2012). A descriptive model of female violent offenders. Psychiatry, Psychology and Law, 19(3), 412-426.

Murphy, D. A., Brecht, M. L., Huang, D., \& Herbeck, D. M. (2012). Trajectories of delinquency from age 14 to 23 in the National Longitudinal Survey of Youth sample. International Journal of Adolescence and Youth, 17, 47-62.

National Archives (n.d). Browse legislation. [Online] Available from: http://www.legislation.gov.uk/browse. [Accessed: $26^{\text {th }}$ July 2015].

Nicholls, T. L., \& Petrila, J. (2005). Psychopathy and gender: An overview of important issues and introduction to the special issue. Behavioural Sciences and the Law, 23, 729-741.

Nicholls, T. L., Cruise, K. R., Greig, D., \& Hinz, H. (2015). Female offenders. In B. L. Cutler \& P. A. Zapf (Eds.), APA handbook of forensic psychology, Vol. 2: Criminal investigation, adjudication, and sentencing outcomes (pp. 79-123). Washington, DC, US: American Psychological Association.

Nieuwbeerta, P., Blokland, A. A. J., Piquero, A. R., \& Sweeten, G. (2011). A life-course analysis of offense specialisation across age: Introducing a new method for studying individual specialisation over the life course. Crime and Delinquency, 57(1), 3-28.

Nwalozie, C. J. (2015). Rethinking subculture and subcultural theory in the study of youth crime - A theoretical discourse. Journal of Theoretical and Philosophical Criminology, 7(1), 1-16.

Pink, B. (2011). Australian and New Zealand Standard Offence Classification (ANZSOC). Canberra, Australia: Australian Bureau of Statistics.

Polaschek, D. L. L. (2006). Violent offender programmes: Concept, theory and practice. In C. R. Hollin \& E. J. Palmer (Eds.), Offending behaviour programmes: Development, application, and controversies (pp. 113-154). Chichester, UK: Wiley.

Pollock, J. M., Mullings, J. L., \& Crouch, B. M. (2006). Violent women: Findings from the Texas women inmates study. Journal of Interpersonal Violence, 21 (4), 485-502. 


\section{DO FEMALE OFFENDERS DIFFER?}

Rettinger, J. L., \& Andrews, D. A. (2010). General risk and need, gender specificity, and the recidivism of female offenders. Criminal Justice and Behavior, 37, 29-46.

Roberts, A. R., Zgoba, K. M., \& Shahidullah, S. M. (2007). Recidivism among four types of homicide offenders: An exploratory analysis of 336 homicide offenders in New Jersey. Aggression and Violent Behavior, 12, 493-507.

Rossegger, A., Weltli, N., Urbaniok, F., Elbert, T., Cortoni, F., \& Endrass, J. (2009). Women convicted for violent offenses: Adverse childhood, limited education and poor mental health. BMC Psychiatry, 9 (81), doi:10.1186/1471-244x-9-81.

Serbin, L. A., \& Karp, J. (2004). The intergenerational transfer of psychosocial risk: Mediators of vulnerability and resilience. Annual Review of Psychology, 55, 333-363.

Shaw, M. (1994). Women in prison: A literature review. Forum on Correctional Research, 6, $13-18$.

Simmons, C., Lehmann, P., Cobb, N., \& Fowler, C. (2005). Personality profiles of women and men arrested for domestic violence. Journal of Offender Rehabilitation, 41 (4), 63-81.

Simons, R. L., Stewart, Es., Gordon, L. C., Conger, R. D., \& Elder, G. H. (2002). A test of lifecourse explanations for stability and change in antisocial behaviour from adolescence to young adulthood. Criminology, 40, 401-434.

Smart, C. (2013). Women, Crime and Criminology: A feminist critique. Oxon, UK: Routledge.

Smit, P., Bijleveld, C., Brouwers, M., Loeber, R., \& Nieuwbeerta, P. (2003). Differences between convicted violent offenders: Completed and attempted homicides and aggravated assaults. In C. R. Block \& R. L. Block (Eds.), Public health and criminal justice approaches to homicide research. Proceedings of the 2003 meeting of the Homicide Research Working Group (pp. 281-286). Chicago, IL: Homicide Research Working Group. 


\section{DO FEMALE OFFENDERS DIFFER?}

Soothill, K., Francis, B., \& Liu, J. (2008). Does serious offending lead to homicide? Exploring the inter-relationships and sequencing of serious crime. British Journal of Criminology, $48(4), 522-537$.

Soothill, K., Francis, B., Ackerley, E., \& Fligelstone, R. (2002). Murder and serious sexual assault: What criminal histories can reveal about future serious offending. Police Research Series No.144. London: Research, Development And Statistics Directorate, Home Office.

Spohn, C. (2000). Thirty years of sentencing reform: The quest for a racially neutral sentencing process. In J. Horney (Ed.), Criminal justice 2000: Policies, processes, and decisions of the criminal justice system (Vol. 3, pp. 427-501). Washington, DC: U.S. Department of Justice.

Steffensmeier, D., \& Allan, E. (1995). Gender, age, and crime. In J. Sheley (Ed.), Handbook of Contemporary Criminology (pp. 83-113). New York: Wadsworth.

Steffensmeier, D., \& Allan, E. (1996). Gender and crime: Toward a gendered theory of female offending. Annual Review of Sociology, 22, 459-487.

Straus, M. A. (2007). Conflict tactics scales. In N. A. Jackson (Ed.), Encyclopedia of domestic violence, (pp. 190-197). New York, NY: Routledge, Taylor and Francis.

Taylor, P. J., Snook, B., Bennell, C., \& Porter, L. (2015). Investigative psychology. In B. L. Cutler \& P. A. Zapf (Eds.), APA handbook offorensic psychology, Vol. 2: Criminal investigation, adjudication, and sentencing outcomes (pp. 165-186). Washington, DC, US: American Psychological Association.

Thornton, A. J. V., Graham-Kevan, N., \& Archer, J. (2012). Prevalence of women's violent and nonviolent offending behavior. Journal of Interpersonal Violence, 27 (8), 1399-1427.

Tillyer, R., Hartley, R.D., \& Ward, J.T. (2015). Differential treatment of female defendants: Does criminal history moderate the effect of gender on sentence length in federal narcotics cases? Criminal Justice and Behaviour, 42(70), 703-721. doi: 10.1177/0093854814560624 


\section{DO FEMALE OFFENDERS DIFFER?}

Tracy, P. E., Wolfgang, M. E., \& Figlio, R. M. (1990). Delinquency in two birth cohorts. New York: Plenum.

Trägårdh, K., Nilsson, T., Granath, S., \& Sturup, J. (2016). A time trend study of Swedish male and female homicide offenders from 1990 to 2010. International Journal of Forensic Mental Health, 1-11. doi: 10.1080/14999013.2016.1152615

Vaughn, M. G., DeLisi, M., Beaver, K. M., \& Howard, M. O. (2008). Toward a quantitative typology of burglars: A latent profile analysis of career offenders. Journal of Forensic Sciences, 53, 1387-1392.

Van Voorhis, P., Wright, E. M., Salisbury, E. J., \& Bauman, A. (2010). Women's risk factors and their contributions to existing risk/needs assessment: The current status of gender responsive assessment. Criminal Justice and Behaviour, 37, 261-288.

Vold, G. B., Bernard, T. J., \& Snipes, J. B. (2002). Theoretical criminology ( ${ }^{\text {rd }}$ ed.). New York: Oxford University Press.

Wermink, H., Johnson, B. D., de Keijser, J. W., Dirkzwager, A. J. E., Reef, J., \& Nieuwbeerta, P. (2016). The influence of detailed offender characteristics on consecutive criminal processing decisions in the Netherlands. Crime and Delinquency, 1-35. doi: $10.1177 / 0011128715624929$

West, S. G., Hatters, S., Friedman, M. D., \& Kim, K. D. (2011). Women accused of sex offences: A gender-based comparison. Behavioural Sciences \& the Law, 29(5), 728-740.

Wright, K. A., Pratt, T. C., \& DeLisi, M. (2008). Examining offending specialisation in a sample of male multiple homicide offenders. Homicide Studies, 12, 381-398.

Youngs, D., Ioannou, M., \& Eagles, J. (2016). Expressive and instrumental offending: Reconciling the paradox of specialisation and versatility. International Journal of Offender Therapy and Comparative Criminology, 60(4), 397-422. doi: 10.1177/0306624X14557478 


\section{DO FEMALE OFFENDERS DIFFER?}

Yourstone, J., Lindholm, T., \& Kristiansson, M. (2008). Women who kill: A comparison of the psychosocial background of female and male perpetrators. International Journal of Law and Psychiatry, 31 (4), 374-383.

Zagar, R. J., Grove, W. M., \& Busch, K. G. (2013). Delinquency best treatments: How to divert youths from violence while saving lives and detention costs. Behavioural Sciences and the Law, 31, 381-396. 
DO FEMALE OFFENDERS DIFFER?

Table 1. Crime Categorisation Schemes in the Current Research

\begin{tabular}{ll}
\hline $\begin{array}{l}\text { Number of } \\
\text { categories }\end{array}$ & Crime categories \\
\hline 4 & Other; Property; Sexual; Violent. \\
8 & Burglary/robbery; Criminal damage; Drugs; Non-notifiable; Other crime; \\
& Sexual; Theft/handling; Violence/against the person. \\
& Abduction; Burglary; Cause injury; Drugs; Fraud; Justice; Miscellaneous; \\
& Property damage; Public order; Robbery; Serious violent; Sexual; Theft; \\
& Traffic; Weapons. \\
& Abduction; Arson; Assault occasioning actual bodily harm (ABH); Attempted \\
& murder; Criminal damage; Domestic burglary; Drug offences; Fraud and \\
& forgery; GBH; Harassment; Homicide; Miscellaneous; Non-domestic \\
& $\begin{array}{l}\text { burglary; Non-notifiable; Other assault; Other theft; Other violence; } \\
\text { Possession of weapon; Robbery; Sexual offences; Theft from vehicle; Theft of } \\
\end{array}$ \\
& Vehicle; Threats to kill; Vehicle interference.
\end{tabular}


Running head: DO FEMALE OFFENDERS DIFFER?

Table 2. Types of Previous Convictions for Female Offenders.

\begin{tabular}{|c|c|c|c|c|c|c|c|c|c|c|c|}
\hline Offence types & $\mathbf{N}$ & $\begin{array}{c}\% \text { SV } \\
(n=206)\end{array}$ & $\begin{array}{c}\text { \% SV: } \\
\text { pre-cons } \\
(n=149)\end{array}$ & $\mathbf{N}$ & $\begin{array}{c}\% \\
\text { Control } \\
(n=1406) \\
\end{array}$ & Offence types & $\mathbf{N}$ & $\begin{array}{c}\% \text { SV } \\
(n=206)\end{array}$ & $\begin{array}{c}\text { \% SV: } \\
\text { pre-cons } \\
(n=149)\end{array}$ & $\mathbf{N}$ & $\begin{array}{c}\% \\
\text { Control } \\
(n=1406)\end{array}$ \\
\hline 4 categories & & & & & & 15 categories & & & & & \\
\hline Other & 94 & 45.6 & 63.1 & 1079 & 76.7 & Traffic & 7 & 3.4 & 4.7 & 148 & 10.5 \\
\hline Property & 65 & 31.6 & 43.6 & 735 & 52.3 & Weapons & 5 & 2.4 & 3.4 & 108 & 7.7 \\
\hline Sexual & - & - & - & 26 & 1.8 & 24 categories & & & & & \\
\hline Violent & 113 & 54.9 & 75.8 & 904 & 64.3 & Abduction & - & - & - & 1 & 0.1 \\
\hline 8 categories & & & & & & Arson & 3 & 1.5 & 2.0 & 38 & 2.7 \\
\hline Burglary/Robbery & 14 & 6.8 & 9.4 & 250 & 17.8 & $\mathrm{ABH}$ & 79 & 38.3 & 53.0 & 551 & 39.2 \\
\hline Criminal damage & 40 & 19.4 & 26.8 & 547 & 38.9 & Assault & 54 & 26.2 & 36.2 & 380 & 27.0 \\
\hline Drug offence & 27 & 13.1 & 18.1 & 408 & 29.0 & Attempted murder & 1 & 0.5 & 0.7 & - & - \\
\hline Non-notifiable & 57 & 27.7 & 38.3 & 550 & 39.1 & Criminal damage & 39 & 18.9 & 26.2 & 533 & 37.9 \\
\hline Other crime & 27 & 13.1 & 18.1 & 257 & 18.3 & Domestic burglary & 6 & 2.9 & 4.0 & 124 & 8.8 \\
\hline Sexual Offences & - & - & - & 26 & 1.8 & Drug offences & 27 & 13.1 & 18.1 & 408 & 29.0 \\
\hline Theft/Handling & 59 & 28.6 & 39.6 & 681 & 48.4 & Fraud and forgery & 9 & 4.4 & 6.0 & 123 & 8.7 \\
\hline Violent & 111 & 53.9 & 74.5 & 896 & 63.7 & $\mathrm{GBH}$ & 10 & 4.9 & 6.7 & - & - \\
\hline 15 categories & & & & & & Harassment & 30 & 14.6 & 20.1 & 355 & 25.2 \\
\hline Abduction & 35 & 17.0 & 23.5 & 364 & 25.9 & Homicide & 1 & 0.5 & 0.7 & - & - \\
\hline Burglary & 10 & 4.9 & 6.7 & 223 & 15.9 & Miscellaneous & 28 & 13.6 & 18.8 & 273 & 19.4 \\
\hline Cause injury & 98 & 47.6 & 65.8 & 726 & 51.6 & Non-domestic burglary & 4 & 1.9 & 2.7 & 148 & 10.5 \\
\hline Drugs & 27 & 13.1 & 18.1 & 408 & 29.0 & Non-notifiable & 51 & 24.8 & 34.2 & 463 & 32.9 \\
\hline Fraud & 9 & 4.4 & 6.0 & 123 & 8.7 & Other theft & 59 & 28.6 & 39.6 & 611 & 43.5 \\
\hline Justice & - & - & - & 1 & 0.1 & Other violence & 4 & 1.9 & 2.7 & 22 & 1.6 \\
\hline Miscellaneous & 52 & 25.2 & 34.9 & 493 & 35.1 & Possession of weapon & 5 & 2.4 & 3.4 & 108 & 7.7 \\
\hline Property damage & 40 & 19.4 & 26.8 & 548 & 39.0 & Robbery & 6 & 2.9 & 4.0 & 52 & 3.7 \\
\hline Public order & 17 & 8.3 & 11.4 & 87 & 6.2 & Sexual offences & - & - & - & 26 & 1.8 \\
\hline Robbery & 6 & 2.9 & 4.0 & 53 & 3.8 & Theft from vehicle & 1 & 0.5 & 0.7 & 90 & 6.4 \\
\hline Serious violent & 12 & 5.8 & 8.1 & - & - & Theft of vehicle & 8 & 3.9 & 5.4 & 131 & 9.3 \\
\hline Sexual & - & - & - & 26 & 1.8 & Threats to kill & 4 & 1.9 & 2.7 & 21 & 1.5 \\
\hline Theft & 62 & 30.1 & 41.6 & 683 & 48.6 & Vehicle interference & 1 & 0.5 & 0.7 & 23 & 1.6 \\
\hline
\end{tabular}


1

2

3

4

5

6

7

8

9

10

11

12

13

14

15

16

17

18

19

20

21

22

23

24

25

26

27

28

29

30

31

32

33

34

35

36

37

38

39

40

41

42

43

44

45

46

47

48

49

50

51

52

53

54

55

56

57

58

59

60

Running head: DO FEMALE OFFENDERS DIFFER?

Table 3. Significant Comparisons between Female SV and Control Offenders for Four Offence Categories, Using Chi-square Analysis

\begin{tabular}{lccccc}
\hline Previous offences & \multicolumn{1}{c}{$\begin{array}{c}\text { SV } \\
(\boldsymbol{n}=\mathbf{1 4 9})\end{array}$} & $\begin{array}{c}\text { Control } \\
(\boldsymbol{n}=\mathbf{4 4 7})\end{array}$ & \multicolumn{2}{c}{$\begin{array}{c}\chi^{2} \\
(\mathbf{O R})\end{array}$} & $\begin{array}{c}\text { Odds Ratio } \\
\end{array}$ \\
\hline Violence & $75.8 \%$ & $60.0 \%$ & 12.226 & 2.096 & $.0001^{* * *}$ \\
Property & $43.6 \%$ & $57.9 \%$ & 9.234 & 0.562 & $.002^{* *}$ \\
\hline$* * * p<.001, * * p<.01$ & & & & &
\end{tabular}

$* * * p<.001, * * p<.01$ 


\section{DO FEMALE OFFENDERS DIFFER?}

Table 4. Significant Comparisons between Female SV and Control Offenders for Eight Offence Categories, Using Chi-square Analysis

\begin{tabular}{lccccc}
\hline \multicolumn{1}{c}{ Previous offences } & $\begin{array}{c}\text { SV } \\
(\boldsymbol{n}=\mathbf{1 4 9})\end{array}$ & $\begin{array}{c}\text { Control } \\
(\boldsymbol{n}=\mathbf{4 4 7})\end{array}$ & \multicolumn{2}{c}{$\begin{array}{c}\text { Odds Ratio } \\
\text { (OR) }\end{array}$} & $p$ \\
\hline Violence & $74.5 \%$ & $59.1 \%$ & 11.413 & 2.025 & $.001 * *$ \\
Theft/handling & $39.6 \%$ & $54.4 \%$ & 9.747 & 0.550 & $.002 * *$ \\
\hline$* * * p<.001, * * p<.01, * p<.05$ & & & &
\end{tabular}


DO FEMALE OFFENDERS DIFFER?

1

2

3

4

5

6

7

8

9

10

11

12

13

14

15

16

17

18

19

20

21

22

23

24

25

26

27

28

29

30

31

32

33

34

35

36

37

38

39

40

41

42

43

44

45

46

47

48

49

50

51

52

53

54

55

56

57

58

59

60

Table 5. Significant Comparisons between Female SV and Control Offenders for 15 Offence Categories, Using Chi-square Analysis

\begin{tabular}{lclllc}
\hline \multicolumn{1}{c}{ Previous offences } & \multicolumn{1}{c}{$\begin{array}{c}\text { SV } \\
(\boldsymbol{n}=\mathbf{1 4 9})\end{array}$} & $\begin{array}{c}\text { Control } \\
(\boldsymbol{n}=\mathbf{4 4 7})\end{array}$ & \multicolumn{1}{c}{$\chi^{\mathbf{2}}$} & \multicolumn{1}{c}{$\begin{array}{c}\text { Odds Ratio } \\
(\mathbf{O R})\end{array}$} & $p$ \\
\hline Cause injury & $65.8 \%$ & $50.1 \%$ & 11.034 & 1.913 & $.001^{* *}$ \\
Public order & $11.4 \%$ & $3.8 \%$ & 12.019 & 3.258 & $.001^{* *}$ \\
Theft & $41.6 \%$ & $54.8 \%$ & 7.795 & 0.588 & $.005^{* *}$ \\
\hline$* * * p<.001, * * p<.01, * p<.05$ & & & &
\end{tabular}




\section{DO FEMALE OFFENDERS DIFFER?}

Table 6. Significant Comparisons between Female SV and Control Offenders for 24 Offence Categories, Using Chi-square Analysis

\begin{tabular}{lccccc}
\hline Previous offences & $\begin{array}{c}\text { SV } \\
(\boldsymbol{n}=\mathbf{1 4 9})\end{array}$ & $\begin{array}{c}\text { Control } \\
(\boldsymbol{n}=\mathbf{4 4 7})\end{array}$ & $\begin{array}{c}\boldsymbol{\chi}^{\mathbf{2}} \\
\text { Odds Ratio } \\
\text { (OR) }\end{array}$ & $p$ \\
\hline ABH & $53.0 \%$ & $38.3 \%$ & 10.005 & 1.822 & $.002 * *$ \\
Ather theft & $39.6 \%$ & $53.2 \%$ & 8.324 & 0.576 & $.004^{* *}$ \\
\hline$* * * p<.001, * * p<.01, * p<.05$ & $26.6 \%$ & 5.020 & 1.567 & $.025^{*}$ \\
\hline
\end{tabular}

